\title{
Г.I. Андрущенко
}

\author{
G.I. Andrushchenko
}

\section{СТРУКТУРА ФОНДУ ЖИТТЕВИХ ЗАСОБІВ ТА Ї̈ СКЛАДОВІ У СОЦІОЛОГІЧНОМУ АСПЕКТІ}

\begin{abstract}
The author considers the economic and sociological sense of the notion "a fund of living means", studies the structure of this fund consisting of two main parts (the natural-material part and the monetary one) from the economic viewpoint, and proposes to improve the fund structure by separating its third part (the socially reproducing one) which realizes the greatest effect on both the formation of a man or a woman as a personality and the reproduction of their role in the society.
\end{abstract}

Сучасне тлумачення поняття “фонд життєвих засобів” (ФЖЗ) фахівцями має суто економічний зміст: ФЖЗ являє собою сукупність предметів споживання і послуг, що об'єктивно необхідні для задоволення особистих потреб людини, забезпечення відтворення і розвитку їі здібностей до праці, утримання непрацездатних членів сім'ї [1, с. 54]. Проте застосування нами соціологічного підходу до цієї категорії дало змогу стверджувати, що дане поняття має значно глибший зміст, аніж це показує економіка. На нашу думку, ФЖЗ необхідно розглядати як основу відтворення біологічної, інтелектуальної, соціальної сутності людини, що проявляється у наявності в неї мети зайняти соціальний статус, гідне місце в суспільстві у професійному та особистісному відношеннях.

Тому метою нашої статті є спроба дослідити структуру ФЖЗ та його складових у соціологічному аспекті, що дасть нам можливість підтвердити правильність вищевикладеної думки, а також більш детально вивчити зміст і сутність ФЖЗ як соціологічної категорії. При цьому, розглядаючи погляди економістів з цього приводу, ми зможемо створити уявлення про структуру ФЖЗ у соціологічному аспекті, дещо змінивши та удосконаливши іiі.

Останнім часом серед провідних українських економістів [2, с. 414-415; 3, с. 360-361] популярною є думка про те, що структура ФЖЗ має дві основні класифікаційні ознаки: тривалість використання товарів та форма розподілу доходів. Проте, на наш погляд, під час аналізу структури ФЖЗ як економічної категорії доцільнішим буде застосовувати ці ознаки не до всього поняття “фонд життєвих засобів", а лише до окремих частин у його структурі.

У економіці зазвичай структура ФЖЗ представлена двома складовими: натурально-речовою та грошовою [1, с. 54]. Ці складові тісно пов'язані між собою, оскільки у процесі життєдіяльності людини грошова частина ФЖЗ часто перетворюється на натурально-речову.

Розглянемо зміст вищезазначених частин ФЖЗ в економічному аспекті більш докладно. При цьому зауважимо, що натурально-речову частину ФЖЗ будемо 
класифікувати за ознакою тривалості користування товарами та послугами, а грошову - за формою розподілу доходів.

Натурально-речова частина ФЖЗ представлена сукупністю предметів споживання та послуг, які за ознакою тривалості користування розподіляються на дві групи: товари і послуги разового користування та товари і послуги тривалого користування.

За економічним підходом до товарів і послуг разового користування належать продукти харчування, послуги транспорту і зв'язку, послуги культурно-освітніх установ, освіти і охорони здоров'я, побутові послуги.

До товарів і послуг тривалого користування належать житло, товари господарсько-побутового і культурного призначення, одяг, взуття, білизна тощо [3, с. 360].

Грошову частину ФЖЗ можна класифікувати за формою розподілу доходів:

1. Доходи, розподіл яких залежить від трудової та підприємницької діяльності:

- заробітна плата тих, хто працює за наймом;

- особисті доходи працівників від реалізації продукції на колективних підприємствах (підприємствах спільного володіння та кооперативах у різних сферах господарювання);

- доходи від індивідуальної трудової діяльності;

- доходи підприємців.

2. Доходи, безпосередньо не пов’язані з оцінкою результатів праці:

- суспільні та благодійні фонди споживання;

- доходи від власності [1, с. 54-55].

Як бачимо, в економічному аспекті структура ФЖЗ включає цінності, що згруповані без врахування їх впливу на процес відтворення сутності людини як особистості, як повноцінного члена суспільства.

Перш за все, це видно зі складу натурально-речової частини ФЖЗ. Так, наприклад, послуги транспорту і зв'язку, послуги культурно-освітніх установ, освіти і охорони здоров'я, побутові послуги тощо за економічною класифікацією вважаються послугами разового користування. Отже, у такому контексті економістів цікавить лише тривалість користування будь-якою із вище наведених послуг.

Проте, з соціологічного погляду, такі послуги, як отримання освіти, медичної допомоги тощо, не є одноразовими. Адже, незважаючи на те, що всі вони за своєю природою є нематеріальними і мають чітко визначену тривалість часу користування, результати від їх надання є дуже важливими для людини. Адже людина користується даними послугами все своє життя; з їх допомогою вона перетворюється на справжню особистість. Те ж саме стосується й продуктів харчування, які люди споживають не один раз, а багато разів з моменту народження і до кінця життя.

Тому вважаємо доцільним вирізнити усі послуги, якими користується людина у процесі своєї життєдіяльності, в окрему (третю) групу, яку умовно назвемо “соціально-відтворююча".

Щодо грошової частини ФЖЗ, то слід відзначити, що соціологію, як і економіку, безперечно цікавить величина доходу і форма його розподілу. Проте найбільше ії цікавить спосіб отримання доходу (законний, чесний він чи ні), мета його використання, а також мотиви такої діяльності людини. Тому, розглядаючи структуру ФЖЗ 
у соціологічному аспекті, слід розглядати всі види доходів, представлені економістами у грошовій частині ФЖЗ. При цьому сюди слід додати й доходи, які стосуються суто ФЖЗ сім'ї і джерела яких не пов’язані з трудовою діяльністю (спадщина, дарування рухомого і нерухомого майна, виграші тощо). Також поширеним видом доходів від нетрудової діяльності людини може бути використання нею соціальних зв'язків. Крім того, до цієї групи доходів важливо додати доходи населення, отримані у тіньовому секторі економіки, наявність яких неможливо ігнорувати, адже вони справляють суттєвий вплив на якість структури ФЖЗ.

Враховуючи вищесказане, вважаємо, що з погляду соціології буде доцільно класифікувати усі перелічені доходи грошової частини ФЖЗ за ознакою джерела отримання доходу, а саме: трудова діяльність, нетрудова діяльність, тіньовий сектор економіки.

Важливо також відзначити, що при складанні власної структури ФЖЗ населення та визначенні ії частин у соціологічному аспекті ми вважаємо за доцільне враховувати досліджувані соціологією складові часу людини. Так, людина використовує час на трьох рівнях - фізичному, біологічному та соціальному. Перші два рівні пов'язані з життєдіяльністю людини як просто живої істоти, що не зазнала еволюції. 3 погляду соціології найбільш цікавим є соціальний час, що характеризує людську діяльність і соціальні відносини під час суспільних процесів. 3 цього приводу соціологія виділяє такі його головні складові: робочий час, який людина присвячує праці, та неробочий час, який людина використовує на власний розсуд.

Неробочий час, у свою чергу, поділяється на час, пов'язаний з домашньою працею і побутовими справами, і час, спрямований на задоволення фізіологічних потреб (сон, споживання їжі тощо), та вільний час.

Вільний час - складова соціального часу, звільнена від виробничих та побутових справ, яка охоплює сферу вільної діяльності людини. Особистий вільний час є в розпорядженні кожної людини і використовується нею відповідно до індивідуальних нахилів, потреб, інтересів, а також можливостей, які надає їй суспільство. Наприклад, це можуть бути такі види занять, як індивідуальне споживання культури (читання книг, журналів, газет, слухання радіо, перегляд телепередач тощо); публічно-видовищне споживання культури (відвідування театрів, кіно, концертів, музеїв, спортивних видовищ тощо) та багато іншого роду занять [4, с. 259].

Таким чином, згідно з наведеним розподілом часу можна сказати, що натурально-речову і грошову частину ФЖЗ людина формує, використовуючи робочий час, а соціально-відтворююча частину вона накопичує у неробочий час, а особливо, у свій вільний час.

Запропонована нами структура ФЖЗ у соціологічному аспекті схематично зображена на рис. 1.

Слід зазначити, що кожний із елементів усіх трьох частин ФЖЗ (натуральноречової, грошової і соціально-відтворюючої) відіграє важливу роль у становленні особистості та набутті нею ролей у суспільстві. У наш час вивченню складових натурально-речової і грошової частини ФЖЗ соціологами та економістами приділено набагато більше уваги, ніж складовим третьої частини. 


\section{СОЦІОЛОГІя}

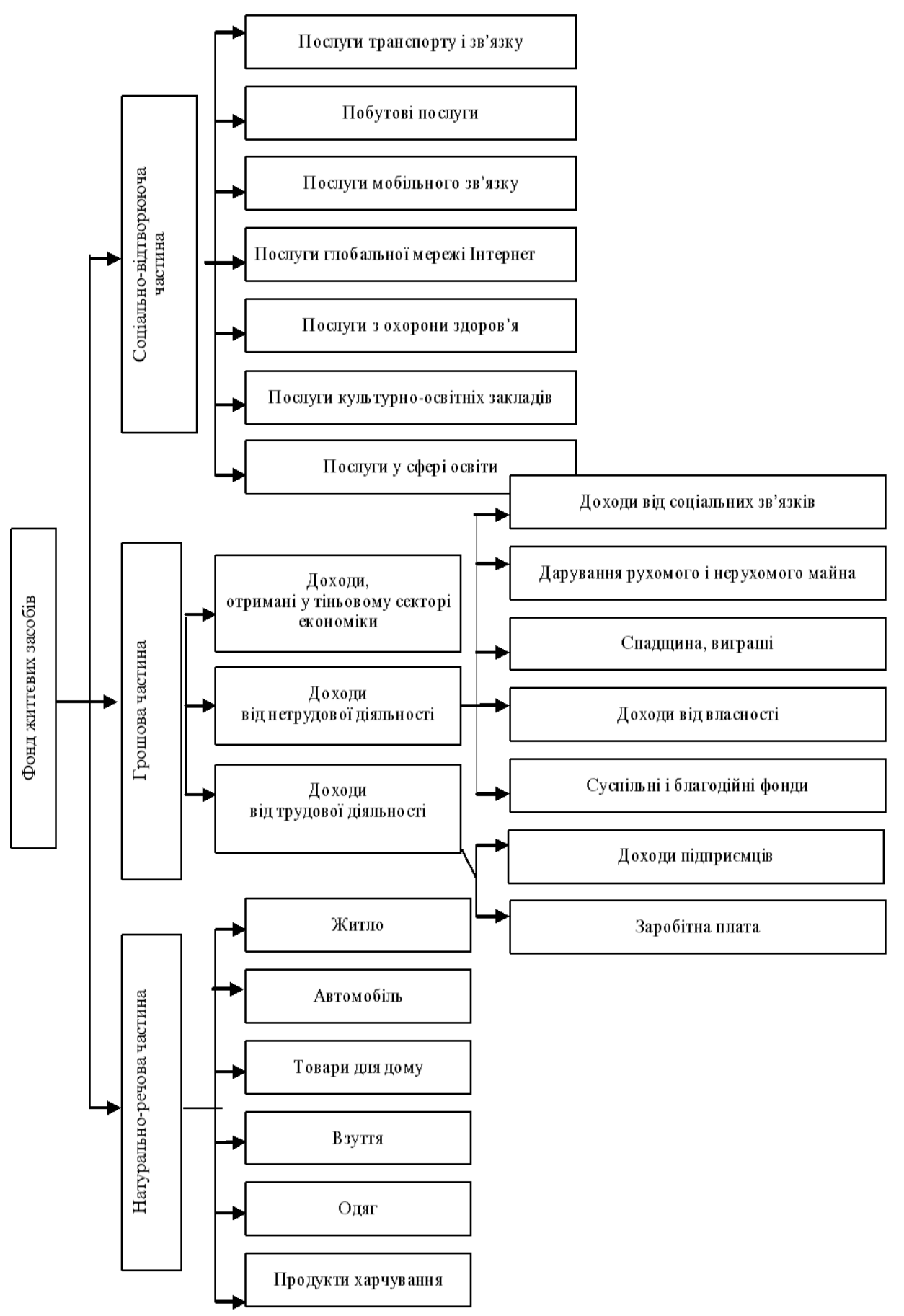

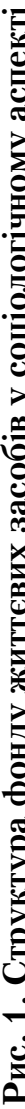


Тому виникає потреба у детальному дослідженні третьої, запропонованої нами, частини ФЖЗ, що за соціологічним підходом здійснює найбільший вплив на формування людини як особистості, їі відтворення, в залежності від чого ми назвали їі “соціально-відтворююча частина ФЖЗ”.

До складу цієї частини ФЖЗ віднесемо такі послуги: послуги освіти і культурно-освітніх установ, послуги всесвітньої мережі Інтернет і мобільного зв’язку, послуги з охорони здоров'я, побутові послуги, послуги транспорту і зв'язку.

Першою розглянемо послугу, яка являє собою отримання людиною освіти. Серед усіх соціальних послуг освіта, на наш погляд, має найбільш вагоме значення для формування особистості, адже чим вище рівень освіти, тим вище ії соціальний статус, тим більше шансів працевлаштування, самореалізації, тим більш обгрунтованою є самоповага. Таким чином, освіта активно бере участь у процесах соціальної диференціації. Крім того, результатами освіти людина користується як упродовж свого повсякденного життя, так і в процесі професійної діяльності.

У соціології існує багато теорій, які по-різному ставляться до поняття освіти. Так, із функціоналістської точки зору, освіта - раціональний спосіб розподілу людей відповідно до їх здібностей, коли найздібніші й найактивніші люди посідають вищі посади. Представники цього напряму вважають, що система освіти сприяє створенню рівних можливостей і сприятливих умов для висхідної мобільності, що в закладах освіти оцінюють людей на основі їхніх досягнень, незважаючи на класову належність, расу і стать тощо.

Згідно з теорією людського капіталу, освіта - це капіталовкладення в тих, хто навчається. Як і всі капіталовкладення, в майбутньому воно принесе прибуток. На основі цього обгрунтовується нерівність дорослих людей, яка зумовлюється кількістю і типом “капіталовкладень”, інвестованих у їх освіту. Таким чином, виправдовується нерівність між людьми, оскільки суспільство здійснило різні витрати на їх підготовку до різних видів діяльності. Винагороди відповідають капіталовкладенням [4, с. 188]. Як бачимо, у цій теорії мова йде про своєрідний кредит, який суспільство надає людині для отримання нею освіти.

Як уже зазначалося раніше, економіка розглядає отримання освіти як послугу разового використання. Проте це твердження суперечить не тільки поглядам соціології, а й історії, оскільки ідеї всеосяжної освіти і постійного навчання зародились ще на ранніх стадіях розвитку людства. Так, на початку XVII ст. Я.А. Коменський писав: "Усе життя є школою для кожної людини. Людині у будь-якому віці призначено вчитись”. Сучасний зміст цієї думки був сформульований на початку 70-х рр. минулого століття, хоча сам термін “освіта протягом усього життя" з'явився в 1960-і рр. під час дискусій, що проходили в ЮНЕСКО з приводу майбутнього розвитку освіти дорослих. Положення в документах ЮНЕСКО були подібними до думки XVII ст.: “Людині у будь-якому віці призначено вчитись, причому у неї мета навчання і $\epsilon$ метою життя" [5, 429].

Проте справжнього визнання ідеї всеосяжної і постійної освіти зазнали лише наприкінці XX ст. завдяки сприятливому розвитку тенденцій та подій у більш широкому політичному, економічному і соціокультурному контексті. Термін “неперервна 
освіта" як “освіта протягом усього життя" і “навчання протягом усього життя” став прямим відображенням надії суспільства на освіту як запоруку виходу із кризи людської цивилізації.

У соціології дослідження поняття освіти зазвичай пов'язують із поняттями “знання” i “виховання”. Якщо знання розглядають як певний ресурс, надбання особистості, то процес освіти являє собою трансляційний, створюючий знання механізм. Під освітою розуміють саме механізм “перетворення", “утворення” особистості, формування все більш досконалого їі образу, згідно з герменевтичною трактовкою слова “освіта". Проте функції системи освіти ніколи не вичерпувалися лише передачею знання. Забезпечуючи людинотворчу функцію, освіта завжди тісно пов'язана з вихованням.

Отже, освіта - це процес і результат формування особистості, її удосконалення за активної позиції самої особистості, яка свідомо і раціонально організована, тому і будується традиційно, спираючись на навчання, а потім на виховання. Виховання ж лежить більше в ірраціональній, емоційній сфері, через що асоціюється із соціальними стереотипами, традиціями, морально-етичними підвалинами [6, с. 397].

Проте за інститутами освіти загальновизнано закріпились функції не тільки навчання та виховання, а й соціалізації. Виховання є провідним і визначальним началом соціалізації, формування свідомості, всебічно розвинутої особи. Соціалізація передбачає процес різнобічного пізнання людиною навколишньої дійсності, оволодіння навиками індивідуальної і колективної праці і творчості, що включає соціальнопсихологічні механізми, з допомогою яких досягається залучення індивіда до людської культури [7, с. 490].

Сьогодні вища школа в Україні стикається з багатьма проблемами. Так, дуже актуальною є проблема дотримання принципу соціальної справедливості, коли сумнівним, навіть для талановитих і перспективних старшокласників, залишаються вступ до вищого навчального закладу і навчання на бюджетних місцях (особливо у престижних закладах).

Це відбувається внаслідок того, що право на отримання освіти переважно визначається рамками ієрархізованої (за майновим і статусним принципами) системи [8, с. 318], оскільки у нашій країні диференціація навчальних закладів і диференціація їх студентів часто сприяє соціальній селекції за матеріальними можливостями батьків [9, с. 322]. На додачу до цього, зараз спостерігається тенденція скорочення державою бюджетних місць в українських ВНЗ.

Дану проблему можна вирішити за допомогою кредитування, що може допомогти людям, які не мають можливості вчитися на бюджетній основі (з різних причин), отримати освіту в будь-якому ВНЗ на більш-менш доступних умовах.

Взагалі, поява платної освіти в Україні обумовлена рядом об'єктивних факторів, перш за все, наявністю платоспроможного попиту на неї. У розвинутих країнах приватна освіта виступає невід'ємною часткою освітнього ринку, займаючи в ньому свою нішу, відмінну від тієї, яку займають державні навчальні заклади [8, с. 319].

Диверсифікованість системи освіти, разом із гнучкою практикою надання абітурієнтам кредитів, робить можливим доступ до вищих навчальних закладів значної 
частини молоді. Та кредитуванню не під силу повністю розв’язати проблему соціальної справедливості. Повне встановлення соціальної справедливості можливе лише в разі проведення державою відповідних заходів.

Слід відзначити той факт, що в наш час важливою є освіта, яку люди отримують поза стінами навчальних закладів. Адже не можна не враховувати впливу на освіту засобів масової інформації, художньої літератури і навіть різноманітного спілкування, подорожей, кола друзів та ін.

Отже, освіта дедалі більше набуває рис вільного розвитку людини, і навіть уявлення про професіоналізм поступово еволюціонує, набуває форми широкої освіченості особистості, що вільно орієнтується в багатьох галузях знань і культури [7, c. 349].

Рівень освіти - міра цивілізації і культури будь-якого суспільства, важливий показник його прогресивного розвитку. Але задовольнити соціальні потреби, підтримувати суспільний прогрес можливо, тільки освоївши багату спадщину культури. Засвоєння людьми досвіду, найзначніших досягнень культури - це не тільки мета і завдання освіти, але і всіх форм культурної діяльності [7, с. 498].

Тому далі розглянемо наступну складову соціально-обслуговуючої частини ФЖЗ - надання послуг культурно-освітніми установами людині, відвідування яких разом із навчальними закладами забезпечує їй різнобічний розвиток як особистості. Перш ніж детальніше дослідити це питання, вивчимо спочатку сутність самого поняття “культура” у соціологічному аспекті.

Культура - це соціальний механізм взаємодії (засоби, способи, зразки взаємодії) особистості, спільноти із середовищем існування (природним та соціальним), які забезпечують передачу досвіду та розвиток перетворюючої діяльності. Культура - це цінності, переконання, зразки, норми поведінки, притаманні певній соціальній групі, певному суспільству. Тобто культурою є не самі по собі цінності, норми, а цінності, норми особи, що забезпечують діяльність та їі розвиток [4, с. 202-203].

Як зазначалося раніше, набуття людиною культурних якостей, задоволення певних культурних потреб відбувається у процесі здійснення нею різних видів діяльності - праці, отримання освіти тощо. Та особливої уваги заслуговує діяльність людини у час, вільний від роботи і навчання, коли вона має можливість відвідувати театри, кіно, концерти, музеї, спортивні змагання тощо. Адже саме у цей період формуються світоглядні орієнтації, духовні потреби, народжується соціальна активність, політична лояльність, повсякденна ментальність та ін. Вільний час допомагає людині набути вищу якість життя, виробити його особливий спосіб, наповнити змістом, що не зводиться до задоволення елементарних потреб.

У залежності від того, як людина використовує свій вільний час, переважно і залежить рівень розвитку її особистої культури, який прямо залежить від способу використання вільного часу, наприклад: задоволення духовних потреб у творчості; пошук розваг; приділення часу домівці, сім'ї, дітям; заняття спортом; виконання громадської роботи; придбання матеріальних благ; заняття антигромадського характеру (пияцтво, вживання наркотиків) тощо. Тому дуже важливим є раціональне використання вільного часу як поєднання видів занять, їх активних і пасивних форм, 
яке найефективніше впливає на особистість, розвиток її сутності, фізичної, емоційної, інтелектуальної сфер життєдіяльності.

У сучасних умовах вільний час, дозвілля стає загальнодоступною культурною цінністю. Будучи протилежністю професійної діяльності, дозвілля стає особливою цінністю життя людини. Так, у теорії комунікації німецького соціолога Ю. Габермаса визначається, що “....людина виступає споживачем дозвілля. Комунікація - засіб захисту споживача, не що інше, як засіб забезпечення безперервності виробничого процесу. Економічна організація сфери вільного часу, тобто створення індустрії дозвілля, перетворення сфери вільної в особливий соціальний інститут - інститут суспільних свобод" [7, с. 346].

Серед деяких вітчизняних соціологів [10, с. 387] існує думка, що вільний час, дозвілля перестає бути простою компенсацією праці, стає необхідністю, перетворюється на “незалежну змінну”, “сенс еволюції розвинених індустріальних суспільств”. Праця ж перестає бути “першою життєвою потребою” і стає лише засобом для самореалізації індивіда, яка здійснюється саме в дозвільній діяльності, надаючи їй соціального значення та самоцінності. На наш погляд, у цих твердженнях справедливо наголошується на зростанні ролі вільного часу для людини внаслідок його впливу на рівень іiі розвитку як члена суспільства, проте зменшувати вагомість праці не варто, адже вона є основним засобом наповнення ФЖЗ.

Таким чином, говорячи про корисність відвідування людиною різноманітних культурно-освітніх закладів, що допомагають їй набути культурних якостей, слід відзначити, що культура формує потреби та інтереси особи, а в остаточному підсумку - певний тип особистості.

Наступною складовою соціально-відтворюючої частини ФЖЗ, роль якої в житті людей за останні роки зростає швидкими темпами, є послуги глобальної мережі Інтернет. Популярності Інтернет набув завдяки тому, що йому вдалося ніби стиснути простір і час, зробити прозорими кордони, надав змогу встановлювати контакти між людьми у різних точках земної кулі. Створений як комунікативна система, Інтернет став новою формою спілкування між людьми.

Слід зазначити, що мережа Інтернет є не тільки швидким способом спілкування між людьми, а й зручним і корисним, дуже змістовним джерелом інформації різного характеру. Адже людина має можливість, не докладаючи ніяких фізичних зусиль, не витрачаючи часу на подорожі до бібліотеки, знайти будь-яку потрібну їй інформацію в Інтернеті. Крім цього, існує ще безліч послуг, які стали можливими завдяки впровадженню цієї всесвітньої мережі. I всі вони є не менш вагомими для забезпечення життєдіяльності людини.

Проте, поряд із незаперечними перевагами включеності у світову інформаційну мережу, важливо усвідомити соціальні ризики та соціально-психологічні наслідки цієї включеності як для соціуму в цілому, так і для окремої особистості зокрема. Адже ця форма спілкування має дуже важливу особливість: вона може не тільки змінювати зміст спілкування, а ще й справляти серйозний вплив на учасників комунікаційного процесу [11, с. 244]. Часто це проявляється в тому, що у людей внаслідок спілкування із широким колом віртуальних співбесідників змінюються інтереси, 
пріоритети i, навіть, життєва позиція. Такі зміни в людині можуть призвести до послаблення іiі локальних соціальних зв'язків, тобто до втрати людиною інтересу спілкування зі своїм близьким оточенням (родичами, друзями, знайомими). До того ж, заміна безпосередньої міжособистісної комунікації спілкуванням з інформаційною машиною багато в чому позбавляє людину ï морально-ціннісного начала.

Крім того, деяких сучасних вітчизняних соціологів [11, с. 245] турбує виникнення разом із мережею Інтернет нового виду соціальної нерівності - інформаційної, заснованої на принципі залучення до світу сучасних технологій, яка виникає між індивідами, соціальними групами і навіть країнами. Різниця у фінансових можливостях людей спричиняє нерівність між тими, хто володіє технічними засобами чи знаннями для отримання необхідної, достовірної та повної інформації, і тими, у кого такі можливості відсутні [6, с. 17; 12, с. 270]. Як наслідок, велика частина населення не має доступу до сучасних засобів зв’язку, втрачає професійну конкурентоспроможність.

Отже, вплив процесу інформатизації на формування людини як члена суспільства є різнобічним: з одного боку, це можливість налагодження контактів із людьми усього світу, з іншого - формується новий стиль життя, коли комп'ютер для людини стає цікавішим за інших людей, з'являються соціальні ризики. Та незважаючи на ці негативні моменти, завдяки всесвітній інформаційній мережі Інтернет, як і завдяки освіті, культурно-масовим закладам, людина розвивається як особистість, відбувається процес її соціалізації.

Аналогічний вплив на формування особистості людини здійснюють послуги мобільного зв'язку. Завдяки появі великої кількості операторів мобільного зв'язку цей вид послуг на Україні є досить доступним. Тому сьогодні вже кожна друга людина (включаючи навіть дітей) має можливість спілкування з іншими членами суспільства незалежно від місця їх розташування.

Останні послуги, які ми розглянемо у складі соціально-відтворюючої частини ФЖЗ, - це послуги охорони здоров’я, транспорту і зв'язку, побутові послуги. Особливістю перелічених послуг є те, що суттєвого впливу на людину як особистість вони не здійснюють. Проте ці послуги виступають важливим показником рівня і якості життя людини, її добробуту. Так склалося в сучасних умовах, що завдяки своїм фінансовим можливостям людина може обирати престижний медичний заклад, вид транспорту та спектр побутових послуг.

Слід відмітити, що грошова частина ФЖЗ може перетворюватись у натурально-речову, (наприклад, якщо заробітну плату витрачено на купівлю продуктів харчування, побутової техніки тощо). Але таке перетворення не є обов'язковим, оскільки інколи грошова частина ФЖЗ або залишається у тому ж вигляді і не змінює свій розмір (наприклад, коли родина вирішила зберігати зароблені гроші вдома), або перетворюється на інший вид грошового доходу у структурі сімейного ФЖЗ (наприклад, коли родина отримує дохід від грошей, покладених на депозит).

Структура ФЖЗ населення, і сім'ї зокрема, є важливим показником рівня її добробуту, задоволення найважливіших потреб. Проте зростання доходів сім'ї не тільки веде до повнішого задоволення її потреб, а й змінює структуру напрямів і переваг 
використання сімейних доходів. При цьому виявляються деякі важливі закономірності цього процесу. Так, харчування у структурі сімейних доходів займає одне 3 найважливіших місць. Зменшення частки витрат на цю статтю є позитивною тенденцією, що засвідчує підвищення життєвого рівня населення. Пояснюється це тим, що видатки на харчування є необхідною основою фізіологічного існування людини, визначаються традиційними сімейними потребами населення і щонайменше піддаються скороченню. Людина економить на харчуванні в останню чергу, коли всі інші ресурси вже вичерпано. Розвиток виробництва, зростання багатства суспільства i його членів зумовлюють збільшення заощаджень і нагромаджень, які використовуються для поліпшення його добробуту.

Наприкінці дослідження складеної нами структури ФЖЗ, можна зробити висновок, що усі три іiї складові впливають на формування людини як особистості. Проте у структурі ФЖЗ найбільше сприяння відтворенню соціальної сутності людини здійснюють складові запропонованої нами третьої частини ФЖЗ - соціально-відтворюючої, адже вони виступають запорукою отримання нею гідного місця у суспільстві. Крім того, наведене на початку цієї статті власне означення ФЖЗ є вірним, оскільки підтверджує наше припущення про те, що ФЖЗ є не тільки економічною, а ще й соціологічною категорією.

1. Лобанова А., Славіна О., Братченко Л. Основи економічної теорії: Навч.-методич. посіб. для студентів вищих педаг. навч. закладів. - Кривий Ріг: КДПУ, 2006. - 132 с.

2. Основи економічної теорії: політ економічний аспект: Підруч. / Г.Н. Климко, В.П. Нестеренко, Л.О., Каніщенко та ін.; За ред. Г.Н. Климка, В.П.Нестеренка. - 2-ге вид., перероб. і допов. - К.: Вища шк. - Знання, 1997. - 743 с. : іл..

3. Основи економічних знань: Навч. посіб. / А. С. Гальчинський, П. С. Єщенко, Ю. І. Палкін. - 2-е вид, перероб. і допов. - К.: Вища шк., 2002. - 543 с. : іл..

4. Соціологія: Підручник для студентів вищих навч. закладів / За ред. В.Г. Городяненка - К.: Видавн. центр “Академія”, 2002. - 560 с. (Альма-матер).

5. Астахова В. И. Непрерывное образование - стратегическое направление развития современных образовательных систем // Зб. матеріалів IV Всеукр. соціол. конф. "Проблеми розвитку соціологічної теорії. Соціальні процеси в Україні”, Київ, 21 травня 2004. - К., 2004. C. $429-431$.

6. Каменская Т. Г. Процессы в современной системе “знание-образование-воспитание” // Там само. С. 396-398.

7. Соціологія: Підруч. / За заг. ред. проф. В П. Андрущенка, проф. М. І. Горлача. - Харків Київ, 1998. - 624 с.

8. Яковенко A. B. Мотивации получения высшего образования в контексте цивилизационных трансформаций // Зб. матеріалів II Всеукр. соціол. конф. "Проблеми розвитку соціологічної теорії. Теоретичні проблеми змін соціальної структури українського суспільства”, Київ, 19 квітня 2002. -К., 2004. - С. 316-320. 
9. Набатчикова E. Н. Высшее образование как фактор социальной стратификации в украин ском обществе // Так само. - С. 321-325.

10. Цимбалюк Н. М. Соціально-структурні виміри сучасного дозвілля // Там само. C. $385-389$.

11. Рудницька T. М. Інтернетизація та вестернизація як чинники формування нового соціокультурного ареалу життя особистості в Україні за умов глобалізації. // Зб. матеріалів IV Всеукр. соціол. конф. "Проблеми розвитку соціологічної теорії. Соціальні процеси в Україні”, Київ, 21 травня 2004. - К., 2004. - С. 244-248.

12. Лобовикова Е. А. Информатизация как новый социальный процесс. // Там само. - С. 270. 